\title{
Performance of green manuring for soil health and crop yield improvement
}

\author{
Muhammad Rafique Sajjad ${ }^{1 *}$, Rizwan Rafique ${ }^{2}$, Riffat Bibi ${ }^{1}$, Adnan \\ Umair $^{1}$, Arslan $\mathrm{Afzal}^{3}$, Arshad Ali ${ }^{3}$ and Tanzila Rafique ${ }^{4}$ \\ 1. Soil and Water Conservation Research Institute, Chakwal-Pakistan \\ 2. Agriculture Department (Extension) Punjab-Pakistan \\ 3. Department of Agronomy, University of Agriculture Faisalabad-Pakistan \\ 4. GC Women University Faisalabad-Pakistan \\ *Corresponding author's email: mrsajjad61@gmail.com
}

Citation

Muhammad Rafique Sajjad, Rizwan Rafique, Riffat Bibi, Adnan Umair, Arslan Afzal, Arshad Ali and Tanzila

Rafique. Performance of green manuring for soil health and crop yield improvement. Pure and Applied Biology.

Vol. 8, Issue 2, pp1543-1553. http://dx.doi.org/10.19045/bspab.2019.80095

\begin{tabular}{llll}
\hline \hline Received: 14/01/2019 & Revised: 24/04/2019 & Accepted: 13/05/2019 & Online First: 16/05/2019 \\
\hline
\end{tabular}

\section{Abstract}

Intensive cultivation, low and imbalance use of fertilizers, soils are continuously depleted and degraded. Green manuring (GM) is a well-known practice performed by the farming communities almost around the globe. Green manure crops are grown and ploughed as green foliage to improve soil characteristics. Leguminous crops have more importance as green manure over non- leguminous crops. Green manuring is one of the important possible options in achieving the ultimate goal of sustainable crop yield improvement. Various studies have highlighted the role of green manuring in improving soil organic matter, soil porosity, water holding capacity and soil C: $\mathrm{N}$ ratio. Fertilizer use efficiency (FUE) is improved by incorporation of green manure crops. It is helpful in sustainable agriculture systems by maximizing the crop yields and improving the livelihood of farming community. High yielding varieties are being introduced at a rapid pace to meet up the current challenges related to food security. Therefore, integrated use of green manuring and fertilizers is the best combination for achieving higher yield. Inclusion of green manure crops in the exiting cropping system has some constraints like availability of quality seed to farmers, performance variability in green manure crops, problems related to its establishment and incorporation as well. Moreover, costly tillage, seeding operations and labor need to be reduced for better adoption of green manure programme. The sole objective of this article was to review the advances in green manuring technology.

Keywords: FUE; Green manuring; Legume crops; Limitations; Profitability; Soil health

\section{Introduction}

Green manuring practice is performed by the farming communities in many parts of the world and it is considered as a popular organic crop amendment [1]. Green manuring is a common method of conserving moisture in the soil and it also improves soil organic matter as well [2]. The crops which are grown and ploughed as green to improve the condition of the soil are called green manure crops. Green manure crops are grown on a piece of land for the purpose of incorporation into the soil as green vegetation for soil health improvement. It is a soil amendment and nutrient source for future crops to improve the yield and sustainable production of major crops. Green manure crops should not be confused with cover crops as they are grown for conservation and their incorporation in soil is not necessary but 
incorporation into the soil is prerequisite in green manure crops [3]. Long term study (thirty four years) in southern USA revealed that cover crops (especially vetch) with notillage management improved infiltration rate of soil and improved the yield of lint cotton [4].

Legumes and non-legumes can be grown as a green manure. The inclusion of nonleguminous crops is due to their fast growing period. Leguminous crops have more importance as green manure over nonleguminous crops because they add organic matter and valuable amount of nitrogen into the soil [5]. In many farming systems around the world, N-fixing leguminous crops are preferred as a green manure [6]. Because, they reduce external inputs for crops and increase the internal resource availability to soil for successful cultivation of major crops [7]. Leguminous green manure crops include all clovers, beans, vetches, alfalfa and lupines. Crops having less water requirement, good crop stand, deep root system, vigorous vegetative growth early in the season and contain large amount of non-fibrous tissues coupled with rapid decomposition ability, having fair percentage of moisture and nutrient supply to the soil are selected for green mauring [3].

Favourable time for sowing of green manure crops is at the onset of monsoon season usually in last week of June in rain-fed conditions. These crops are allowed to stand in field up to mid -August and incorporated when there is maximum biomass [2]. Suitable time of green manure crop incorporation in the soil is when there are enough green leaves, immature pods, vegetative buds and flowers because the decomposition is rapid. As the plant becomes aged, it contains old shoots and other hard woody parts; however decomposition is a problem due to the presence of complex lignin compounds [8]. Sunhemp (Crotalaria juncea L.), susbania (Sesbania aculeate), cowpea (Vigna unguiculata), Chickling vetch (Lathyrus staivus L.), soybean (Glycine max L.), cluster bean(Cyamopsis tetragonoloba), alfalfa (Medicago sativa L.), Egyptian clover (Trifoliam alexandrium L.), wild indigi (Indegofera tinctoria L.), pigeon pea (Cajanus cajan L.), forage pea (Pisum sativum L.), mungbean (Vigna radiata), velvet bean (Mucuna deeringiana) and black lentil (Lens culinaris) are the major green manure crops $[9,10]$.

Intensive cultivation degrades the basic resources for crop production and nutrient availability is interlinked with organic matter which is depleting continuously. When the organic matter is reduced, a serious decline in nutrient availability appears in the soil. In natural systems, equilibrium is present within the bio-mass production and reserve sources but there is net removal of nutrients characterized by low storage capacity, less cycling efficiency and continuous loss of nutrients [11]. This continuous loss of nutrients and organic matter is a major threat to the earth's ability to feed the rising population. Land degradation is a major agricultural concern because it has negative effects on crop production which ultimately leads to food security issues. About $78 \%$ nitrogen is present in the environment but plants are unable to use this nitrogen because plants require mineralized $\left(\mathrm{NH}_{4}{ }^{+}\right.$and $\left.\mathrm{NO}_{3}{ }^{-}\right)$ nitrogen [12]. Excessive use of chemical fertilizer is an emerging issue in sustainable agriculture production and ecological point of view [13].

\section{Green manuring for sustainable agriculture}

Concerning soil sustainability and crop productivity scientist takes keen interest in green manuring and organic fertilization [14] who revealed interesting facts that beneficial effects of green manuring in crop production should be evaluated in integration with chemical fertilizers and in isolation. In agricultural system mostly $\mathrm{N}$ fertilizers are 
used and the efficiency of nitrogenous fertilizer is very low because most of the nitrogen in the form of nitrate $\left(\mathrm{NO}_{3}{ }^{-}\right)$leaches down and leaves the root zone and ultimately enters in the groundwater [15, 16] which causes health problems in humans and animals. Leaching of ammonium $\left(\mathrm{NH}_{4}{ }^{+}\right)$ causes problem only when it is applied in very large quantities in coarse textured soils. Green manures are preferred over other organic fertilizers because these crops are grown directly in the field and are easier to incorporate during land preparation or regular weeding operations [17]. Adoption of green manuring allied to the fertilizers is the basic need on the basis of current emerging issues. Green manuring is a viable alternative to summer fallowing in agriculture systems [10].

Multiple benefits can be achieved by green manuring. Humus in the soil is very much important for crop growth and green manure adds a reasonable amount of humus into the soil. One of the most important benefits is that green manure adds a valuable amount of $\mathrm{N}$ and organic matter in the soil [18]. Some green manure plants have deep root system and can help to uplift nutrients from the deeper soil layers and when incorporated in soil, release nutrients in the upper layer of soil from where the next crop can easily get nutrients. Soil is a major component of all agricultural systems; the basic units are soil structure and its aggregates [19] while organic matter plays a vital role in aggregate and structure stability of soil [20].

\section{Green manuring an eco-friendly approach} Use of environmental friendly organic manure like green manure is one of the best remedies for improving soil fertility and increase soil water use efficiency in dry land cropping system [21]. Soil properties such as aeration, porosity, conductivity and infiltration are directly allied to the soil structure. Green manures improve the moisture condition, temperature and aeration of soil. It helps in soil water conservation [22] which is a major problem in rain-fed areas; management practices can increase the water storage in the soil [23]. Moisture conservation is increased because the soil physical properties are directly linked to the water storage in soil. Apart from this, it is helpful in the suppression of weeds, nematodes and erosion control [24, 25]. Furthermore, it resulted in reduced weed density by cultivation of different green manure crops and helped in integrated weed management (IWM) in maize/cassava intercropping [26]. Green manure $\left(\mathrm{GM}_{20}\right)$ along with fertilizer nitrogen $\left(\mathrm{FN}_{60}\right)$ decreased potential for ground water $\mathrm{NO}_{3}{ }^{-}$ contamination [27].

\section{Soil health and green manuring}

Soil health is one of the major requirements for successful plant growth. But most of agricultural soils are deficient in organic matter and nutrients. If practices for soil health improvement and maintenance are not included in agricultural system, it can be very hazardous in future. Improvements in soil physical and chemical properties are attributed to the integrated use of green manure and fertilizers due to better nutrient uptake [28]. Therefore, green manuring practice in our agricultural system is also helpful in maintaining the soil health. Incorporation of green manure improved soil nutrient status. Improvement of soil organic carbon was about $12 \%$ higher over recommended practices. Soil NPK improvement was 12 to $21 \%$ by green manuring [29]. Soil organic matter, soil health and crop growth was significantly improved by the addition of green manure crops [30]. Decrease in soil $\mathrm{pH}$ and increase in soil organic carbon was observed after three weeks of vetch green manuring compared to fallow [31].

Green manure crops are not only nitrogen providers but incorporation of these crops as green manure adds organic matter to the soil. 
Organic matter plays a vital role in the arrangements of soil aggregates and makes a stable soil structure [20]. Soil organic carbon and nitrogen content was increased with the addition of cowpea as green manure [32]. Sand, silt and clay are the soil aggregate and are basic units for soil structure. Soil structure, soil quality and productivity is improved by the addition of organic refuse [19]. There is direct relationship of decomposability of organic products and their impact on aggregate stability. Therefore, organic matter decomposition has very important role in making the aggregate stability and a stable soil structure [33]. Practices of organic matter and green manuring addition can be used as amendments for agricultural land [20]. Another study on green manure application revealed that it enhances the organic matter contents in the soil [34]. Decomposition of the organic matter is affected by many factors but temperature is one of the important factors [35]. Green manure (GM) and farmyard manure (FYM) replenished the soil organic matter (SOM). Soil organic carbon and nitrogen contents were achieved ranging from 0.10 to 1.40 and 0.05 to 0.55 through the soil amendment practices [36].

Soil physical properties are helpful for establishing the functional ability of the soil for the maintenance of crop growth, which is influenced by the sustainable agricultural management practices. Application of nitrogen and rye green manure has no effect on the soil physical properties but it provides the basic nutrients for the growth of crop [3739]. An inverse relationship exists between the bulk density and total porosity, which is a measure of porous spaces left in soil for the movement of free water and air in these pore spaces [38, 40]. Reduction in bulk density results in greater porosity and it improved aeration, progressing in a suitable environment for biological action of living organisms [41, 42]. Soil granulation and pores size both progressively increase by the incorporation of leguminous crops as a green manure crop in the soil [43]. Soil aeration depends upon pore size allocation in the soil, which is very important for water and air balance in the pore spaces [44]. Significant reduction in soil bulk density with an associated increment in total porosity of the soil was observed by the application of sesbania. This may be correlated with greater amount of the organic matter decomposition and loosening of the soil particles with the action of microbes on the roots of sesbania crop [45]. Soil texture, structure and amount of organic matter contents all have key role in controlling the porosity of soil [23]. Aggregate size affects the pore sizes of the soil. Soil structure had direct and indirect effect on microbial processes that take place in soil and crop roots [46].

Soil primary particles and micro-aggregates are converted into the macro-aggregates through the physical actions in the roots and construction of cementing agents which ultimately enhance the microbial activities and all these have effects on the soil structural properties. Bulk density is reduced due to the aggregation processes and properties, which not only enhances the porosity but also improves the water holding capacity and transmission capabilities [37, 39, 40, 41, 47]. Maximum reduction of $7 \%$ in soil bulk density was noted by the application of sesbania as a leguminous green manure crop which has good impact on increasing the total porosity and available water up to the $17 \%$ when sesbania used as a green manure crop [48].

\section{Green manuring and crop yield potential}

Agricultural systems are leading towards intensification. Inclusion of green manuring in our agricultural system is one of the most important factors for sustainable agriculture because green manure crops not only maintain but also improve the soil characteristics. These crops are also directly 
or indirectly involved in the yield improvement of the subsequent crop. It can be helpful for maximizing the yield of major crops. It is therefore, dire need for improvement in our agricultural system to get maximum benefits from high yielding varieties by improving the soil health. The use of green manuring alone is not enough. Integrated use of manuring and fertilizer should be enough to cope with the requirements of high yielding varieties for crop production $[49,50]$. Green manuring is helpful in enhancing wheat grain yield significantly during four out of six growing seasons [51]. In a rice-wheat cropping system sesbania as a green manure is suggested for marginal benefits of high yielding varieties [50]. In addition, green manuring of cowpea following wheat resulted in significantly higher wheat yield by $19-20 \%$ compared to wheat-rice system [32]. Sugarcane yield can be improved with the incorporation of leguminous green manure crop, increase in stalk height, tiller number/plant, crop vigor and yield was observed after 6 and 12 months of planting [52]. Urea application at the rate of $20 \mathrm{~kg} \mathrm{~N} \mathrm{ha}^{-1}$ after 50 days of planting along green manuring of dhaincha substituted urea at $40 \mathrm{~kg} \mathrm{~N} \mathrm{ha-1} \mathrm{[53].} \mathrm{Green} \mathrm{manures}$ preferably the leguminous green manures not only improve the efficiency of nutrient uptake but also reduce the use of fertilizer. In a rice-wheat cropping system a four years research on sandy loam soil showed that rice yield was increased by incorporating cowpea
(Vigna unguiculata L) or sesbania (Sesbania aculeata). Wheat yield was also improved by residual GM, indicating that fertilizer nitrogen applied to wheat could be reduced by $25 \%$. Integrated use of green manure and fertilizer for rice-wheat rotation demonstrated greater yield of rice and wheat [27]. Similarly, maize grain yield was enhanced significantly $(\mathrm{p}<0.05)$ by green manuring [54].

Green manure and mineral fertilizer application ratio is very important because it varies in different cropping systems. Therefore, a balanced nutrition programme integrating green manuring along mineral fertilizers is necessary for sustainable crop production. Productivity of rice was improved by In situ green manuring with sunhemp. Maximum yield was observed with $100 \%$ NPK+green manure, which were at par with $75 \%$ NPK+green manure. However, the values were lowest under $100 \%$ NPK application [29]. A related study (Table 1) in rain-fed conditions of Pothwar plateau revealed that incorporation of cowpea in wheat-cowpea-wheat cropping system compared with wheat-fallow-wheat resulted in $13.5 \%$ increase in wheat grain yield, wheat straw by $14 \%$, productive tillers by $7 \%$ and plant population by $4 \%$. It also improved soil moisture up to $11.8 \%$ as well [22]. There is need for further studies on monitoring of green manuring and organic amendment programmes, particularly in rain fed parts of the world.

Table 1. Effects of cowpea green manuring on improving wheat yield and soil moisture [22]

\begin{tabular}{|c|c|c|c|c|c|}
\hline \multicolumn{2}{|c|}{ Soil moisture } & Plant & Productive & $\begin{array}{c}\text { Wheat straw } \\
\text { yield }\end{array}$ & $\begin{array}{c}\text { Wheat grain } \\
\text { Yillers }\end{array}$ \\
\hline $0-15 \mathrm{~cm}$ & $15-30 \mathrm{~cm}$ & population & $7 \% \uparrow$ & $14 \% \uparrow$ & $13.5 \% \uparrow$ \\
\hline $3.6 \% \uparrow$ & $11.8 \% \uparrow$ & $4 \% \uparrow$ & $7 \% \uparrow$ & 0.14 & \\
\hline
\end{tabular}

\section{Green manuring and fertilizer use efficiency (FUE)}

Fertilizer use efficiency (FUE) is improved by incorporation of green manure crops. Reduction in fertilizer $\mathrm{N}$ use was $25-50 \%$ by the integration of green manuring $\left(\mathrm{GM}_{20}\right)$ with fertilizer nitrogen $\left(\mathrm{FN}_{60}\right)$ for a ricewheat rotation [27]. Fertilizer efficiency is decreased by leaching of nitrogen in the form of $\mathrm{NO}_{3}{ }^{-}$and contaminates the ground water. 
Green manuring has its residual effects for more than one year. Incorporation of cowpea as green manure resulted in less nitrogen addition due to improved nitrogen availability and increased nitrogen use efficiency [32]. Leguminous green manure crop involves in nitrogen fixation in the soil and provide nitrogen for the next crop and also include the organic matter in the soil. Improvement in soil nitrogen concentration, biomass production and higher grain yield was observed with leguminous green manure crop (sesbania and cowpea) application after fallow treatment. Another major attribute for the use of green manure is the planting population of green manure crop. Different populations give different results for the subsequent crop. Successful improvement in the maize yield can be achieved by green manuring of cowpea with plant population of 80,000 plants per ha and it can be helpful to the small farmers for improving soil health as an alternative to fertilizer [55].

\section{Economic profitability}

Higher productivity under green manuring resulted in higher return and more benefitcost ratio. In situ green manuring is a viable low-cost technology for enhancing productivity and profitability [29]. The highest net return was observed under $100 \%$ NPK+green manuring (Rs. 8371 ha $^{-1}$ ) followed by $75 \%$ NPK+green manure (Rs. $6613 \mathrm{ha}^{-1}$ ) and $50 \% \mathrm{NPK}+$ green manure (Rs. $\left.6553 \mathrm{ha}^{-1}\right)$. Significant improvement in net return was observed with the inclusion of green manuring in the system [29]. In another study it was observed that green manuring resulted in 16.8 per cent increase compared to check. Overall performance of cowpea green manuring in wheat (Figure 1) was positive and the benefit was Rs $10283 \mathrm{ha}^{-1}$ [22]. However, the trend is not always positive, there are some exceptions as reported by [56] who observed some negative trends and revealed that possible long term benefits are not always indicated by short term yield or production. Therefore, continuous and long term monitoring of green manuring programme is necessary [22].

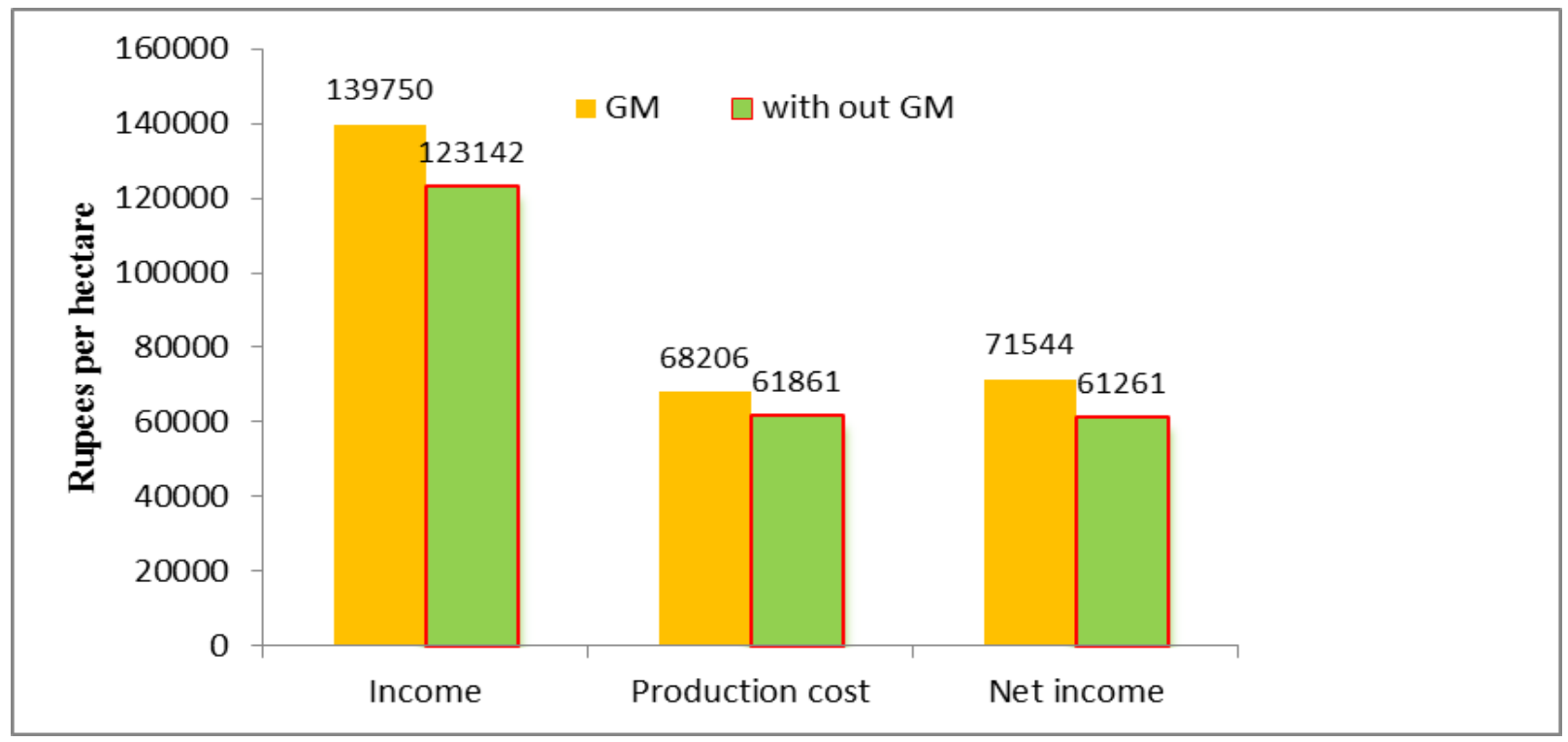

Figure1. Cost benefit analysis of cowpea green manuring for wheat crop [22] 


\section{Constraints in adoption of green manuring}

Green manuring practice has some limitations for its adoption. Some of the issues are identified by several reviews and several surveys in different cropping systems $[57,58]$. Unplanned and unwise green manure application may result in nitrogen deficiency due to nitrogen immobilization [14]. Further, water deficiency for subsequent crops under arid and semi-arid conditions is a major issue as green manure crops also consume soil moisture [59]. Unstable wheat yield was observed by leguminous green manure crops due to more soil moisture consumption [60]. Moreover, leguminous green manure quality seed is not easily available. Variability of green manure performance particularly in problematic soils, establishment and incorporation of green manure is costly, absence of appropriate machinery [61]. Tillage, seeding operation, land and labor charges not allow the farmers to do green manuring. Seed production for green manures is costly, further control of pest and pathogens is also problematic issue in green manures [62], because these are the desirable food sources for them. These crops cannot provide direct cash to farmers, so they have an opinion that there is no need to invest in protection measures for it. Furthermore, timing, growth stage and synchronization of green manure crop with the cropping pattern are crucial factors. High water requiring crops are not suitable in arid regions [14]. In many countries there is no subsidy to the farmers on growing of green manures, so the farmers are not willing for adopting a thing other than the conventional.

\section{Conclusion}

There is an acute pressure on our soil resources to meet the rising demand of food supply through intensification of agriculture system around the world. As the population of world has been rising at a rapid rate and more efforts are being focused towards raising crop production through improved crop resources, introduction of short duration, resistant and high yield varieties. However, soil health, its sustainability and productivity, which are largely threatened due to unwise agricultural practices, need to be conserved if not possible to improve. Use of organic amendments such as green manure crops which provide us a window of opportunity in ameliorating soil health, fertility status and productivity potential. It helps in soil moisture conservation and increases water holding capacity of soil by improving soil physio-chemical properties and soil organic matter; hence it increases water use efficiency (WUE). Leguminous green manure crops help in nitrogen fixation and increase fertilizer use efficiency (FUE), thus help in integrated nutrient management (INM). It also suppressed weeds in cropping systems particularly under monoculture agricultural practice by integrated weed management (IWM) programme. Incorporation of green manure crops reduced fertilizer cost, increased crop yield and net profitability as well. Overall, it is an ecofriendly practice for soil health and sustainable production. Although, it is a good practice for improving soil health and crop yield but there are some constraints related to it in different cropping systems. Therefore, there is need for further research on reducing the risks involved with it particularly in rainfed conditions with little rainfall during the growing season. Selection of crops for green manuring and time of its incorporation in different cropping systems need to be standardized for minimizing the risks involved in the use of green manure crops.

\section{Authors' contributions}

Conceived and designed the experiments: MR Sajjad \& R Bibi, Performed the experiments/ Review: MR Sajjad, A Afzal, R Bibi \& R Rafique, Analyzed the data: MR Sajjad \& R Rafique, Contributed materials/ analysis/ tools: A Afzal, A Ali \& A Umair, 
Wrote the paper: MR Sajjad, R Rafique, A Afzal \& T Rafique.

\section{Acknowledgements}

The authors highly acknowledge Dr. Abdul Majid, Country Manager, ICARDA Pakistan for sparing his precious time and valuable suggestions for the improvement of this manuscript.

\section{References}

1. Bai Y, Yan Y, Zuo W, Gu C, Xue W, Mei L, Shan Y \& Feng K (2017). Coastal mudflat saline soil amendment by dairy manure and green manuring. Inter $J$ Agron 2017: 1-9.

2. Hasan ZA, Khan A, Jha AK, Razzaq A, Sajjad MR \& Muhammad G (2014). Green manuring for improved wheat yield through moisture conservation in rainfed areas of Pakistan. J Agri Food Appl Sci 2(6): 171-173.

3. Singh S, Singh RJ, Kumar K, Singh B \& Shukla L (2013). Biofertilizers and Green manuring for sustainable agriculture, 1st edn. New India Publishing Agency, New Delhi, 129150.

4. Nouri A, Lee J, Yin X, Tyler DD \& Saxton AM (2019). Thirty-four years of no-tillage and cover crops improve soil quality and increase cotton yield in Alfisols, Southern USA.Geoderma. 337: 998-1008.

5. Carlsson G \& Huss-Danell K (2003). Nitrogen fixation in perennial forage legumes in the field. Plant Soil 253: 353372.

6. Ramos, MG, Villatoro, MAA, Urquiaga S, Alves, BJ \& Boddey RM. (2001). Quantification of the contribution of biological nitrogen fixation to tropical green manure crops and the residual benefit to a subsequent maize crop using $15 \mathrm{~N}$-isotope techniques. J Biotechnol 91(2-3): 105-115.
7. Bohlool BB, Ladha JK, Grrrity DP \& George T (2004). Biological nitrogen fixation for sustainable agriculture: a perspective. Plant Soil 141: 1-11.

8. Ghosh PK, Bandyopadhyay KK, Wanjari RH, Manna MC, Misra AK, Mohanty M \& Rao AS (2007). Legume Effect for Enhancing Productivity and Nutrient Use-Efficiency in Major Cropping Systems- An Indian Perspective:A Review. J Sustain Agr 30: 59-86.

9. Fageria NK \& Baligar VC (2005). Enhancing nitrogen use efficiency in crop plants. Adv Agron 88: 97-185.

10. Mooleki SP, Gan Y, Lemke RL, Zentner RP \& Hamel C (2016). Effect of green manure crops, termination method, stubble crops, and fallow on soil water, available N, and exchangeable P. Can J Plant Sci 96: 867-886.

11. Hendrix PF, Coleman DC \& Crossley DA (1992). Using Knowledge of nutrient cycling processes to design sustainable agriculture. J Sustain Agr 2: 63-81.

12. Hirel B, Gouis JL, Ney B \& Gallais A (2007). The challenge of improving nitrogen use efficiency in crop plants: towards a more central role for genetic variability and quantitative genetics within integrated approaches. J Exp Bot 58: 2369-2387.

13. Aulakh MS \& Pasricha NS (1998). The effect of green manuring and fertilizer $\mathrm{N}$ application on enhancing crop productivity in mustard-rice rotation in semi-arid subtropical regions. Eur J Agron 8: 51-58.

14. Fageria NK (2007). Green manuring in crop production. J Plant Nutr 30: 691719.

15. Olson RJ, Hensler RE, Attoe OJ, Witzwl SA \& Peterson LA (1970). Fertilizer nitrogen and crop rotation in relation to movement of nitrate nitrogen through 
soil profiles. Soil Sci Soc Am Proc 34: 448-452.

16. Spalding RF \& Kitchen LA (1988). Nitrate in the intermediate vadose zone beneath irrigated cropland. Ground Water Monit Rev 8:89-95.

17. Tamiru H (2013). Effect of kill time of legume green manures on growth and nutrient uptake of succeeding maize (Zea mays L). Int J Agron Plant Prod 4: 36233636.

18. Aulakh MS \& Pasricha NS. 1997. Effect of green manuring and fertilizer $\mathrm{N}$ application on enhancing crop productivity in mustard-rice rotation in semiarid subtropical regions. Eur $J$ Agron 8:51 58.

19. Caravaca F, Lax A \& Albaladejo J (2001). Soil aggregate stability and organic matter in clay and fine silt fractions in urban refuse-amended semiarid soils. Soil Sci Soc Am J 65: 1235-1238.

20. Annabi M, Houot S, Francou C, Poitrenaud M \& Bissonnais YL (2007). Soil aggregate stability improvement with urban composts of different maturities. Soil Sci Soc Am J 71: 413423.

21. Zhang DB, Yao PW, Li J, Zhao N, Wang $\mathrm{Z}, \mathrm{Yu} \mathrm{CW}, \mathrm{Cao} \mathrm{QH}, \mathrm{Cao}$ WD \& Gao YJ (2013). Effects of two years incorporation of leguminous green manure on soil properties of a wheat field in dryland conditions. Acta Ecologica Sinica 33: 2272-2281.

22. Sajjad MR, Subhani A, Rafique R, Hussain T, Naseem W, Bibi R \& Malik SN (2018). Green manuring for moisture conservation and wheat yield improvement in rainfed agricultutre. $J$ Nat Sci Res 8: 33-41.

23. Martens DA \& Frankenberger WT (1992). Modification of infiltration rates in an organic-amended irrigated soil. Agron J 84: 707-717.
24. Chikoye D, Ekeleme F \& Udensi UE (2001). Cogongrass suppression by intercropping cover crops in corn/cassava systems. Weed Sci 49:658667.

25. Osei K, Gowen SR, Pembroke B, Brandenburg RL \& Jordan DL (2010). Potential of leguminous cover crops in management of a mixed population of root-knot nematodes (Meloidogyne spp.). J Nematol 42: 173.

26. Olorunmaiye PM (2010). Weed control potential of five legume cover crops in maize/cassava intercrop in a Southern Guinea savanna ecosystem of Nigeria. AJCS 4(5): 324.

27. Aulakh MS, Khera TS \& Doran JW (2000). Yield and nitrogen dynamics in a rice-wheat system using green manure and inorganic fertilizer. Soil Sci Soc Am J 64: 1867-1876.

28. Patra DD, Anwar A \& Chand S (2000). Integrated nutrient management and waste recycling for restoring soil fertility and productivity in Japanese mint and mustard sequence in Uttar Pradesh. Indin Agr Ecosys Environ 80: 267-275.

29. Kumar N, Mina BL \& Chandra S (2011). In-situ green manuring for enhancing productivity, profitability and sustainability of upland rice. Nutr $\mathrm{Cycl}$ Agroecosys 90: 369-377.

30. Salahin N, Alam MK, Islam MM, Naher L \& Majid NM (2013). Effects of green manure crops and tillage practice on maize and rice yields and soil properties. Aust J Crop Sci 7: 1901.

31. Belachew T \& Abera Y (2011). Effect of green manuring in combination with nitrogen on soil fertility and yield of bread wheat (Triticum aestivum) under double cropping system of Sinanadinsho, Southeast Ethiopia. JBES 1: 111.

32. Yadav RL, SinghVK, Dwivedi BS \& Shukla AK (2003). Wheat productivity 
and $\mathrm{N}$ use-efficiency as influenced by inclusion of cowpea as a grain legume in a rice-wheat system. J Agri Sci 141: 213220.

33. Abiven S, Menasseri S \& Chenu C (2009). The effects of organic inputs over time on soil aggregate stability - A literature analysis. Soil Biol Biochem 41: $1-12$.

34. Melero S, Porras JCR, Herencia JF \& Madejon E (2006). Chemical and biochemical properties in a silty loam soil under conventional and organic management. Soil Tillage Res 90: 162 170.

35. Fierro A, Angers DA \& Beauchamp CJ (1999). Dynamics of physio-organic matter fractions during d-inking paper sludge decomposition. Soil Sci Soci Am J 63: 1013-1018.

36. Zubair M, Anwar F, Ashraf M, Ashraf A $\&$ Chatha SAS (2012). Effect of Green and Farmyard Manure on Carbohydrates Dynamics of Salt-Affected Soil. J Soil Sci Plant Nut 12: 497-510.

37. Ekwue EI (1990). Organic matter effects on soil strength properties. Soil Till Res 16: 289-297.

38. Min DH, Islam KR, Vough LR \& Weil RR (2003). Dairy manure effects on soil quality properties and carbon sequestration in alfalfa-orchard-grass systems. Commun Soil Sci Plant Anal 34: 781-799.

39. Scott HD, Mauromoustakos A, Handayni IP \& Miller DM (1994). Temporal variability of selected properties of Loessial soil as affected by cropping. Soil Sci Soc Amer J 58: 15311538.

40. Tester CF (1990). Organic amendment effects on physical and chemical properties of a sandy soil. Soil Sci Soc Amer J 54: 827-831.

41. Islam KR \& Weil RR (2000). Land use effects on soil quality in a tropical forest ecosystem of Bangladesh. Agric Ecosyt Environ 79: 9-16.

42. Werner MR (1997). Soil quality characteristics during conversion on organic orchard management. Appl Soil Ecol 5: 151-167.

43. Chikowo R, Mapfumo M, Nyamugafat $P$ \& Giller KE (2004). Woody legume fallow productivity, biological nitrogen fixation and residual benefits to two successive maize crops in Zimbabwe. Plant Soil 262: 303-315.

44. Aon MA, Sarena DE, Burgos JL \& Cortassa S (2001). Microbiological, chemical and physical properties of soils subjected to conventional or no-till management: an assessment of their quality status. Soil Till Res 60: 173-186.

45. Lampurlanes J \& Martinez C (2003). Soil bulk density and penetration resistance under different tillage and crop management systems and their relationship with barley root growth. Agron J 95: 526-536.

46. Van Veen JA \& Kuikman PJ (1990). Soil structural aspects of decomposition of organic matter by micro-organisms. Biogeochem 11: 213-233.

47. Goldhamer DA, Grimes DW, Culick SH \& Munk DS (1994). Cover-cropped enhanced water infiltration of a slowly permeable fine sandy loam. Soil Sci Soc Amer J 58: 1539-1546.

48. Sultani MI, Gill MA, Anwar MM \& Athar M (2007). Evaluation of soil physical properties as influenced by various green manuring legumes and phosphorus fertilization under rain fed conditions. Inter J Environ Sci Technol 4: $109-118$

49. Dikemann KH, De Datta SK \& Ottow JCG (1993). Nitrogen uptake and recovery from urea and green manure in lowland rice measured by ${ }^{15} \mathrm{~N}$ and nonisotope techniques. Plant Soil 148: 9199. 
50. Yadav RI (2001). On farm experiments on integrated nutrient management in rice-wheat cropping systems. Exp Agr 7: 99-113.

51. Ghuman BS \& Sur HS (2006). Effect of manuring on soil properties and yield of rainfed wheat. J Indian Soc Soil Sci 54: 6-11.

52. Gana AK \& Busari LD (2001). Effect of Green Manure and Farmyard Manure on Growth and Yield of Sugarcane. Sugar Tech 3: 97-100.

53. Sharma AR \& Ghosh A (2000). Effect of green manuring with Sesbania aculeata and nitrogen fertilization on the performance of direct-seeded floodprone lowland rice. Nutr Cycl Agroecosys 57: 141-153.

54. Fabunmi TO, Agbonlahor MU, Odedina JN \& Adigbo SO (2012). Profitability of pre-season green manure practices using maize as a test crop in a derived savanna of Nigeria. Pak J of Agr Sci 49: 593-596.

55. Fabunmi TO \& Agbonlohor MU (2012). The economics of maize production under different cowpea-based green manure practices in the derived savanna zone of Nigeria. J Org Syst 7: 5-13.

56. McGuire AM, Bryant DC, \& Denison RF (1998). Wheat yields, nitrogen uptake, and soil moisture following winter legume cover crop vs. fallow. Agron J 90: 404-410.

57. Ladha JK, Pareek RP \& Becker M (1992). Stem-nodulating legumeRhizobium symbiosis and its agronomic use in lowland rice. Adv Soil Sci 20: 147192.

58. Roger PA \& Watanabe (1986). Technologies for utilizing biological nitrogen fixation in wetland rice: Potentialities, current usage and limiting factors. Fert Res 9: 39-77.

59. Aase JK, Pikil JL, Prueger JH \& Hatfield JL (1996). Lentil water use and fallow water loss in semiarid climate. Agron $J$ 88:723-728.

60. Yao ZY, Wang Z, Li J, Yu CW, Cao QH, Cao WD \& Gao YJ (2015). Effects of rotations and different green manure utilizations on crop yield and soil fertility. J Appl Ecol 26: 2329-2336.

61. Becker M, Ladha JK \& Ali M (1995). Green manure technology: Potential, usage, and limitations. A case study for lowland rice. Plant Soil 174: 181-194.

62. Dabney SM, Schreiber JD, Rothrrock CS \& Johnson J (1996). Cover crops affect sorghum seedling growth. Agron $J$ 88: 961-970. 